\title{
New records of Dendrobrachia bonsai (Octocorallia: Gorgonacea: Dendrobrachiidae) in the western Mediterranean Sea
}

\author{
STÉPHANE SARTORETTO \\ IFREMER, Zone Portuaire de Brégaillon, BP 33083500 La Seyne-sur-Mer, France
}

\begin{abstract}
New Records of Dendrobrachia bonsai have been reported in various locations along the western coast of Corsica. These findings offer additional information on the northern distributional limits of this very scarcely-known gorgonian in the western Mediterranean basin.
\end{abstract}

Keywords: Gorgonacea, Dendrobrachia bonsai, Mediterranean, distribution, new records

Submitted 21 November 2011; accepted 21 November 2011

\section{INTRDDUCTION}

Our knowledge of marine biodiversity in the Mediterranean Sea is essentially focused on coastal areas, whereas data relating to deep zones (beyond the continental shelf) remains limited (Fredj \& Laubier, 1985; Myers et al., 2000; Sardà et al., 2004; Coll et al., 2010). Among the anthozoans living on the slope, Dendrobrachiidae Brook, 1889, form a scarcely-known group, initially considered as an antipatharian family (Thomson, 1910) until it was definitively classified taxonomically as Octocorallia by Opresko \& Bayer (1991), and later Berntson et al. (2001). This gorgonian family is represented by a single genus (Dendrobrachia), which comprised only three species until the early 1990s: Dendrobrachia fallax Brook, 1889; Dendrobrachia multispina Opresko \& Bayer, 1991; and Dendrobrachia paucispina Opresko \& Bayer, 1991. These species were initially found at a limited number of locations in the Atlantic (Cape Verde Islands, southern Florida and Ascension Island) (Brook, 1889; Thomson, 1910), then more recently in south-western Australia (Opresko \& Bayer, 1991). In the Mediterranean Sea, Zibrowius \& Taviani (2005) have reported the presence of colonies of Dendrobrachia (initially thought to be D. fallax) at several locations in the Alboran Sea and in southern Sicily at depths between 230 and $632 \mathrm{~m}$. Cruises conducted in 2007 on-board the RV 'Urania' confirmed the presence of this octocorallian in the south of Malta. In the framework of the TTR (Training Through Research Unesco Programme) also allowed the identification of Dendrobrachia colonies in the Gibraltar Strait. On the basis of these new records and of collections compiled during previous cruises, López-González \& Cunha (2010) described two new species: Dendrobrachia bonsai and Dendrobrachia sarmentosa. same year, samples obtained during cruises conducted in the

Between 2008 and 2010, two cruises were conducted with the aim of exploring submarine canyon-heads along the French coasts and for characterizing their habitats and the associated benthic macrofauna and ichthyofauna. Sites harbouring Dendrobrachia bonsai were discovered during these two cruises. This note presents these results, coupled with a discussion on the northern distributional limits of this species in the western Mediterranean basin.

\section{MATERIALS ANDMETHDDS}

The data were obtained during two cruises: MEDSEACAN (on the continental coasts of France; $03^{\circ} 10^{\prime} \mathrm{E}, 42^{\circ} 25^{\prime} \mathrm{N}-$ $07^{\circ} 30^{\prime} \mathrm{E}, 43^{\circ} 00^{\prime} \mathrm{N}$ ) and CORSEACAN (western coast of Corsica; $\left.\quad 09^{\circ} 20^{\prime} \mathrm{E}, \quad 43^{\circ} \mathrm{Oo} 0^{\prime} \mathrm{N}-09^{\circ} 00^{\prime} \mathrm{E}, \quad 41^{\circ} 25^{\prime} \mathrm{N}\right)$. During these cruises, 27 underwater canyons were explored. Although bionomic research had already been conducted on some of these canyons (Reyss, 1970; Bourcier \& Zibrowius, 1973), most of them are little known or completely unknown, particularly in Corsica. The two field cruises were conducted on-board the RV 'Minibex'. The 'Super Achille' ROV (remotely operated vehicle) and the two-man operated submarine 'Remora' were used for explorations up to depths of $700 \mathrm{~m}$. A total of $240 \mathrm{ROV}$ transects and 21 submarine dives were performed. A colony of Dendrobrachia and a fragment of another colony were collected using the ROV, in the month of August 2010. The samples were stored on-board in $70 \%$ alcohol for identification and collection.

\section{RESULTS AND DISCUSSIDN}

\section{SYSTEMATICS}

Corresponding author:

S. Sartoretto

Email: stephane.sartoretto@ifremer.fr
Order GORGONACEA Lamouroux, 1816

Family DENDROBRACHIIDAE Brook, 1889 
Genus Dendrobrachia Brook, 1889

Dendrobrachia bonsai López-González \& Cunha, 2010

(Figure 1)

\section{MATERIAL EXAMINED}

Research vessel 'Minibex', CORSEACAN cruise, ROV 'Super Achille' dive no. POACHPo5, Canyon of Porto, $42^{\circ} 19.66^{\prime} \mathrm{N}$ $8^{\circ} 34.39^{\prime} \mathrm{E}, 300 \mathrm{~m}$ depth, rocky wall with isolated colonies of Dendrobrachia, 3 August 2010, fragment of colony (total length (TL) $50 \mathrm{~mm}$ ).

Research vessel 'Minibex', CORSEACAN cruise, ROV 'Super Achille' dive no. POACHPo9, Canyon of Porto, $42^{\circ} 19.86^{\prime} \mathrm{N} 8^{\circ} 35.43^{\prime} \mathrm{E}, 218 \mathrm{~m}$ depth, rocky wall with concretions and dense population of Dendrobrachia, 6 August 2010, one colony (TL $90 \mathrm{~mm}$ ).

Additional material was observed and photographed underwater, but not collected.

\section{DESCRIPTION}

The Dendrobrachia samples were examined using the identification key drawn up by López-González \& Cunha (2010). The entire colony collected in the Canyon of Porto was fragile and ramified in one plane. It possessed non-retractile polyps void of sclerites. The cross-section of its distal branches shows the presence of four axial peaks, plus rows of spines on the largest branches. A few spines were present on the main axis below the first ramification. This colony was characterized by mature distal polyps, with oocytes of approximately $0.7 \mathrm{~mm}$ in diameter (Figure $1 \mathrm{~A}$ ). The presence of fertile polyps was observed on a 50-mm fragment collected from another colony in the same canyon, and on in situ photographs taken by the 'Remora' ROV (Figure $1 \mathrm{~B}$ ). The presence of sexually mature polyps during summer in Corsica thus confirms the observations of López-González \& Cunha (2010) in the Mediterranean Sea and Gulf of Gadiz.

\section{BIOGEOGRAPHICAL AND ECOLOGICAL ASPECTS}

Despite similar sampling efforts and same investigation means used during the MEDSEACAN and CORSEACAN cruises, no Dendrobrachia colonies were observed in the underwater canyons explored along the French continental coast. In contrast, Dendrobrachia was found on the western coast of Corsica in five canyons situated between the Gulf of St
Florent and the Gulf of Ajaccio (Figure 2). These observations corroborate the conclusions of López-González \& Cunha (2010), asserting that D. bonsai is the most common species of the genus in terms of geographical and depth distribution. These records are also the northernmost observations of the species in the Mediterranean Sea; to date, D. bonsai had only been observed in the Alboran Sea and in the Strait of Sicily (López-González \& Cunha, 2010). Its absence along the coasts of continental France could result from unfavourable environmental conditions, such as high sediment transport rates resulting from direct connections between rivers and canyons (e.g. Rhône, Var) (Savoye \& Piper, 1991; Berne et al., 1999; Hugot et al., 2001) and specific hydrodynamic conditions such as downwelling of cold water into certain canyons during the winter months (Durrieu de Madron et al., 1999; Canals et al., 2006).

Dendrobrachia bonsai colonies were observed between 200 and $500 \mathrm{~m}$ depth, mainly along the rocky walls and overhangs of high underwater cliffs. It was also encountered on biogenic concretions (thanatocoenosis of NeopycnodonteDesmophylllum) and on isolated rocks relatively free of sediment deposits situated at the foot of cliffs. The colonies were scattered (isolated individuals or small groups) between 300 and $500 \mathrm{~m}$ depth. Conversely, denser aggregations of colonies occupying several square metres were mainly observed between 200 and $300 \mathrm{~m}$. At this level, the in situ photographs taken by the ROV allowed the estimation for maximum densities of 50 colonies per square metre. The benthic fauna associated with these aggregations predominantly comprises hydroids, gorgonians (Acanthogorgia hirsuta, Bebryce mollis and Muriceides lepida), antipatharians (Leiopathes glaberrima and Paranthipates larix), sponges and brachiopods (Grypheus vitreus) (Figure 3 ).

Sightings of Dendrobrachia bonsai along the Corsican coast confirm the affinity of this gorgonian with hard substrates (rock and bioconcretions), at depths ranging from 220 to $600 \mathrm{~m}$ previously observed in the Mediterranean Sea (Zibrowius \& Taviani, 2005; López-González \& Cunha, 2010). Nevertheless, the depth range where dense Dendrobrachia bonsai aggregations were observed and the associated species tend to indicate that this gorgonian has a particular preference for the upper bathyal stage (between 200 and $300 \mathrm{~m}$ ) where currents are significant and a limited amount of sediment is deposited on the substrate.
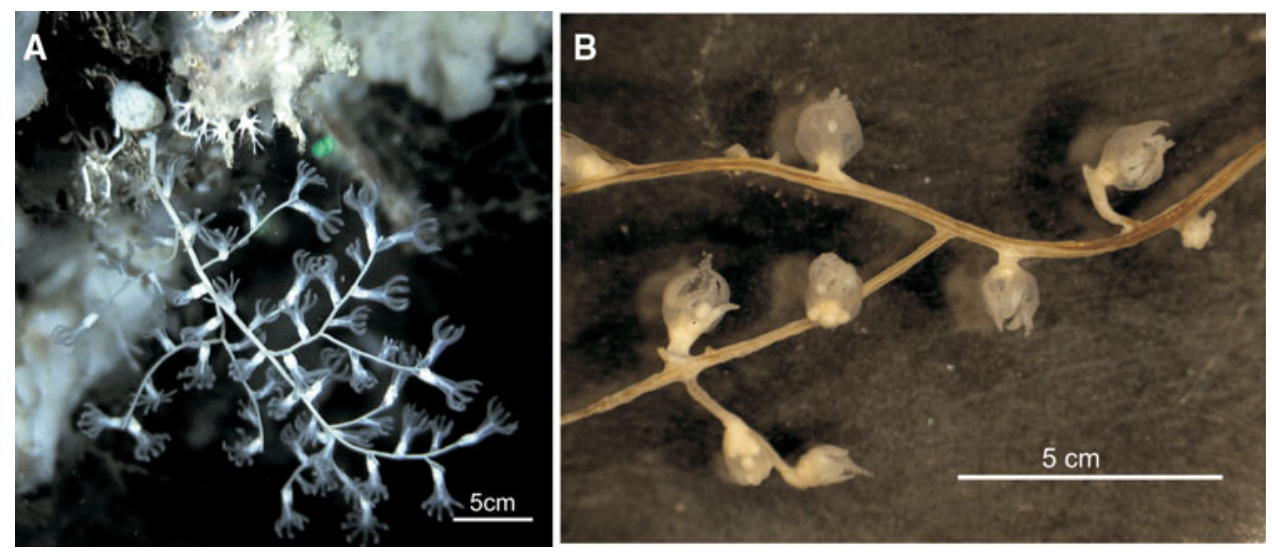

Fig. 1. Dendrobrachia bonsai: underwater photographs of (A) a colony, Canyon of Porto ( $-199 \mathrm{~m})$; (B) a colony collected in the Canyon of Porto ( $-218 \mathrm{~m})$ showing polyps with oocytes. 

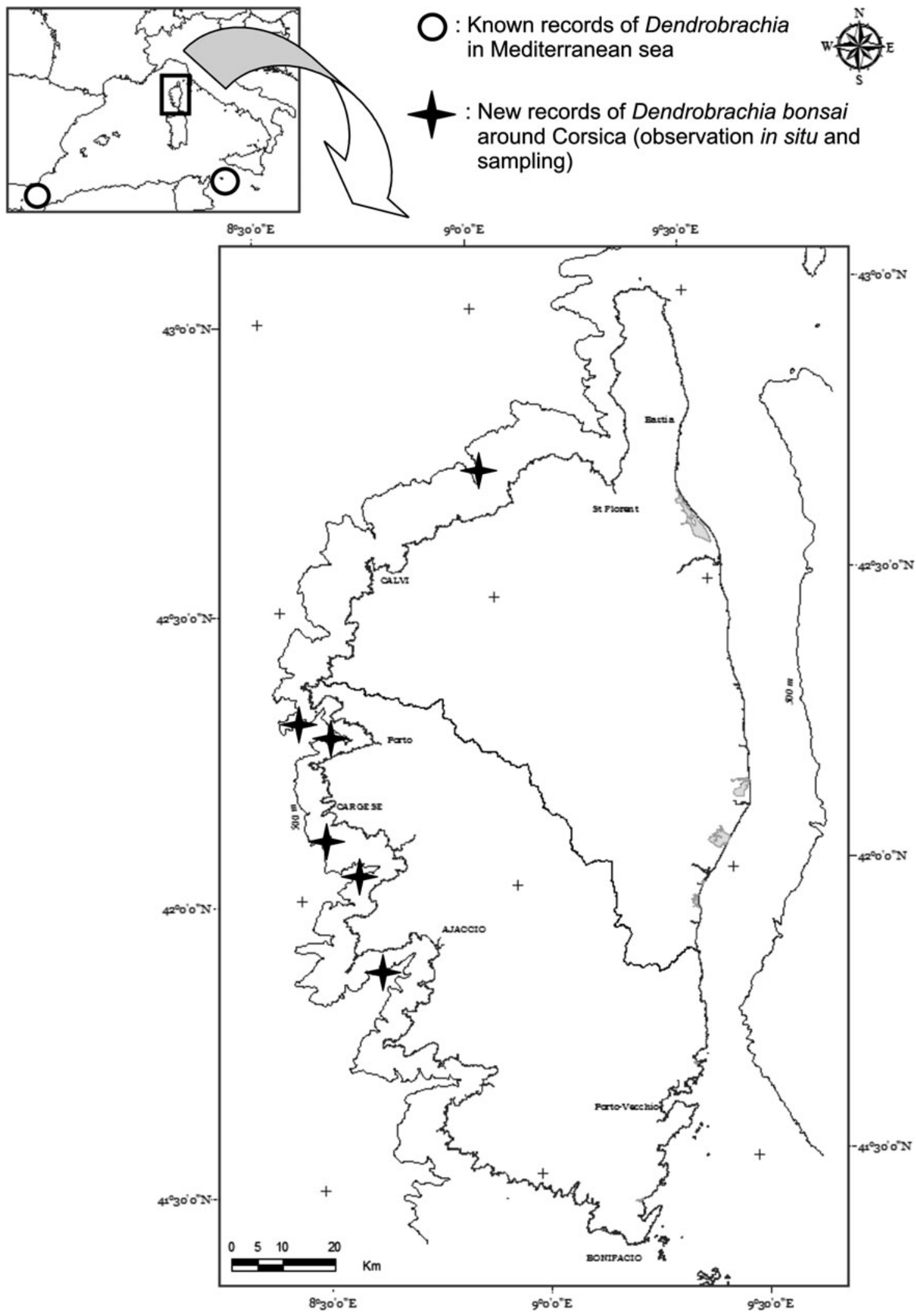

Fig. 2. Distribution of Dendrobrachia bonsai and the location of new records along the Corsican coasts.

\section{ACKNDWLEDGEMENTS}

I would like to thank the Marine Protected Areas Agency (France) for organizing and financing the MEDSEACAN and CORSEACAN cruises, and the COMEX S.A. crews and pilots who took part in them. I also address special thanks to Dr Pablo López-González from the University of Seville. 

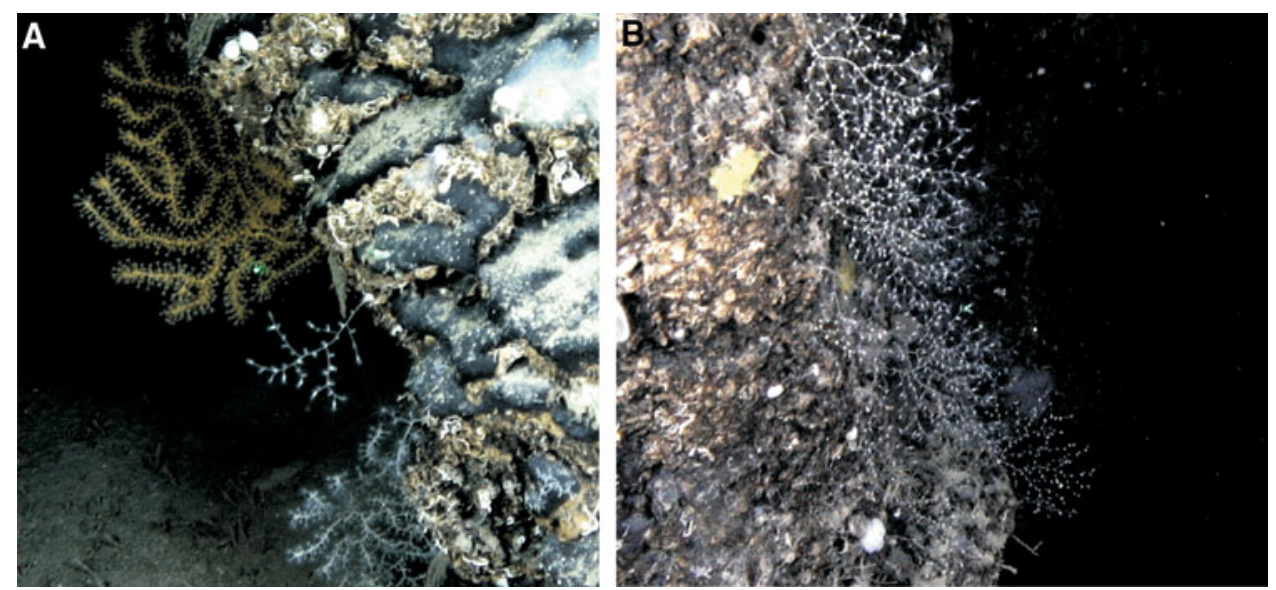

Fig. 3. Dendrobrachia bonsai on deep rocky walls. (A) Colonies of D. bonsai associated with other gorgonians (Acanthogorgia hirsuta and Muriceides lepida); (B) a dense population on a rocky wall.

\section{REFERENCES}

Berne S., Loubrieu B. and équipe Calmar (1999) Canyons and recent sedimentary processes on the western Gulf of Lions margin. First results of the Calmar cruise. Comptes Rendus de l'Académie des Sciences, Serie II, Fascicule (a)_Sciences de la Terre et des Planètes $328,471-477$.

Berntson E.A., Bayer F.M., McArthur A.G. and France S.G. (2001) Phylogenetic relationships within the Octocorallia (Cnidaria: Anthozoa) based on nuclear 18s rRNA sequences. Marine Biology $138,235-246$.

Bourcier M. and Zibrowius H. (1973 (1972)) Les 'boues rouges' déversées dans le canyon de la Cassidaigne (région de Marseille). Observations en soucoupe plongeante SP 350 (juin 1971) et résultats de dragages. Téthys 4, 811-841.

Brook G. (1889) Report on the Antipatharia. Report of the Scientific Results of the Voyage of H.M.S. Challenger, Zoology 32, 1-222, pls $1-15$.

Canals M., Puig P., Durrieu de Madron X., Heussner S., Palanques A. and Fabres J. (2006) Flushing submarine canyons. Nature 444, 354-357.

Coll M., Piroddi C., Steenbeek J., Kaschner K., Ben Rais Lasram F., Aguzzi J., Ballesteros E., Bianchi C.N., Corbera J., Dailianis T., Danovaro R., Estrada M., Froglia C., Galil B.S., Gasol J.M., Gertwagen R., Gil J., Guilhaumon F., Kesner-Reyes K., Kitsos M.S., Koukouras A., Lampadariou N., Laxamana E., López-Fé de la Cuadra C., Lotze H.K., Martin D., Mouillot D., Oro D., Raicevich S., Rius-Barile J., Ignacio Saiz-Salinas J., San Vicente C., Somot S., Templado J., Turon X., Vafidis D., Villanueva R. and Voultsiadou E. (2010) The biodiversity of the Mediterranean Sea: estimates, patterns, and threats. Plos One 5, 1-36.

Durrieu de Madron X., Radakovitch O., Heussner S., Loye-Pilot M.D. and Monaco A. (1999) Role of the climatological and current variability on shelf-slope exchanges of particulate matter: evidence from the Rhone continental margin (NW Mediterranean). Deep-Sea Research I $46,1513-1538$.

Fredj G. and Laubier L. (1985) The deep Mediterranean benthos. In Moraitou-Apostolopoulou M. and Kiorstsis V. (eds) Mediterranean marine ecosystems. New York: Plenum Press, NATO Conference Series no. 8, pp. 109-145.

Hugot A., Joseph P., Savoye B. and Zaleski S. (2001) Nouvelle modélisation des écoulements gravitaires sous-marins: application à l'effondrement de Nice de 1979. Comptes Rendus de l'Académie des Sciences (série II) 333, 133-139.

López-González P. and Cunha M. (2010) Two new species of Dendrobrachia Brook, 1889 (Cnidaria: Octocorallia: Dendrobrachiidae) from the north-eastern Atlantic and western Mediterranean. Scientia Marina 74, 423-434.

Myers N., Mittermeier R.A., Miettermeier C.G., Da Fonseca Gustavo A.B. and Kent J. (2000) Biodiversity hotspots for conservation priorities. Nature $403,853-858$.

Opresko D.M. and Bayer F.M. (1991) Rediscovery of the enigmatic coelenterate Dendrobrachia, (Octocorallia: Gorgonacea) with descriptions of two new species. Transactions of the Royal Society of South Australia 115, 1-19.

Reyss D. (1970) Bionomie benthique de deux canyons sous-marins de la mer Catalane: le Rech du Cap et le Rech Lacaze-Duthier. PhD thesis. Faculté des Sciences de Paris, France.

Sardà F., Calafat A., Mar Flexas M., Tselepides A., Canals M., Espino M. and Tursi A. (2004) An introduction to Mediterranean deep-sea biology. Scientia Marina 68, Supplement 3, 7-38.

Savoye B. and Piper D.J.W. (1991). The Messinian event on the margin of the Mediterranean Sea in the Nice area, southern France. Marine Geology 97, 279-304.

Thomson J.A. (1910) Note on Dendrobrachia fallax Brook, a rare and remarkable antipatharian. Journal of the Royal Microscopical Society 1910, $142-143$.

and

Zibrowius H. and Taviani M. (2005) Remarkable sessile fauna associated with deep coral and other calcareous substrates in the Strait of Sicily, Mediterranean Sea. In Freiwald A. and Roberts J.M. (eds) Cold-water corals and ecosystems. Erlangen Earth Conference Series VI, 807-819. doi: $10.1007 / 3-540-27673-4 \_42$

Correspondence should be addressed to:

S. Sartoretto

IFREMER

Zone Portuaire de Brégaillon

BP 33083500 La Seyne-sur-Mer

France

email:stephane.sartoretto@ifremer.fr 